ISSN 1392-3196 / e-ISSN 2335-8947

Zemdirbyste-Agriculture, vol. 101, No. 2 (2014), p. 199-204

DOI $10.13080 / \mathrm{z}-\mathrm{a} .2014 .101 .026$

\title{
Cultivation technology influences the occurrence of potato early blight (Alternaria solani) in an organic farming system
}

\author{
Eve RUNNO-PAURSON, Merili HANSEN, Berit TEIN, Kaire LOIT, Kätlin JÕGI, Anne LUIK, \\ Luule METSPALU, Viacheslav EREMEEV, Ingrid H. WILLIAMS, Marika MÄND \\ Institute of Agricultural and Environmental Sciences, Estonian University of Life Sciences \\ Kreutzwaldi 1, 51014 Tartu, Estonia \\ E-mail: eve.runno-paurson@emu.ee
}

\begin{abstract}
Nowadays, organically produced products have become more popular than ever and interest in them is still growing fast. The early blight causal pathogen Alternaria solani has not been considered a great threat to potato in northern climate conditions in the past and has not been routinely sprayed against. During our study early blight was evaluated in 2010 and 2011 on the plants of a potato cultivar 'Reet' in an organic farming experiment. In our study, both growing seasons were very favourable for early blight development. Significant differences between the two cultivation technologies were found $\left(F_{1,2}=4.84, p=0.048\right)$. In 2010, the area under disease progress curve (AUDPC) value was 303 on cover crop (CC) plots and 990 on CC + M (manure) plots that is three times higher, whereas in 2011, the AUDPC value was 967 on CC plots and 1195 on CC + M plots. Our results confirm that potato early blight has become a serious problem in North-East European organic potato fields and thus susceptible potato cultivars cannot be recommended for growing in an organic farming system. However, it is possible to influence the development severity of early blight by selecting the proper growing technology. Since, in the changing climate conditions and in susceptible cultivars, early blight is a potato disease that can cause early defoliation of plants and crop death, there is a need for resistant potato cultivars.
\end{abstract}

Key words: Alternaria solani, disease severity, organic growing system.

\section{Introduction}

Potato early blight, caused by the pathogens Alternaria solani (Ellis and G. Martin) L.R. Jones and Grout and A. alternata (Fr.) Keissl., is one of the most destructive fungal foliar diseases in many potato growing regions (Shtienberg et al., 1990; Leiminger, Hausladen, 2012). In susceptible cultivars, it leads to early defoliation and death of the crop (Pelletier, Fry, 1989). The disease occurs particularly in regions with high temperature and alternating periods of dry weather and high humidity and/ or in irrigated potato soils that are light-textured, sandy, and low in organic matter (Gudmestad, Pasche, 2007). By contrast, potato late blight (Phytophthora infestans) is the most destructive potato disease in North-East European conditions due to its diverse populations (Runno-Paurson et al., 2010;2011; 2012; 2014); it is quite difficult to control and needs numerous and consistent applications of fungicides for effective control as in other temperate regions (Cooke et al., 2011; Runno-Paurson et al., 2013).

However, occasionally Alternaria solani does cause a severe incidence of early blight in potatoes in the Nordic/Baltic region and application of fungicides is necessary to control it (Salonen et al., 2001). In recent years, early blight has occurred with increasing frequency in potato fields in northern regions, especially on fields with susceptible potato cultivars and damage has been more serious than before due to changed climate conditions (Kocmánková et al., 2010). Moreover, Jönsson et al. (2013) predict further increase in warmer summers, which could cause greater problems from this pathogen in northern regions. In Latvia, Treikale et al. (2008) have reported increased potato early blight damage in recent years on potatoes grown as a monoculture with a high level of nitrogen. Based on disease frequency monitoring, early blight has become more important as a pathogen in recent years in Germany and in Poland (Latorse et al., 2010). Epidemics caused by Alternaria species can cause significant economic damage to potato production if not sufficiently chemically controlled (Kapsa, Osowski, 2004; Leiminger, Hausladen, 2012). For organic potato producers the main challenge is disease management, which is limited by regulations that prohibit the use of synthetic pesticides (EU-regulation 2092/91). Thus, early blight represents a risk to crop production and results in significant yield losses (Rotem, 1994). In conventional cultivation in a warm and dry growing season, early blight susceptible cultivars need to be sprayed against the pathogen; otherwise haulms can be destroyed too early in the growing season (Kapsa, Osowski, 2004; Treikale et al., 2008). Growing more resistant cultivars of potato is considered the most efficient, cost-effective 
and environmentally-friendly control method for both conventional and organic growing systems. However, growing early blight resistant cultivars is not widespread (Dita Rodriguez et al., 2006). The locally bred potato cultivar 'Reet' was described by breeders Tsahkna and Tähtjärv (2008) as quite late, blight resistant and medium ripening with potential to form tubers early, and therefore is suitable for growing in an organic farming system. Also the cultivar 'Reet' has good quality characteristics like shallow eyes, regular shape and no darkening which are important for food market requirements and processing factories, all very important qualities for marketing (Tsahkna, Tähtjärv, 2008).

In the organic cultivation system, different alternative fertilizers and cultivation technologies including cattle manure and green manure are used to maintain and enhance soil fertility. Studies have shown that winter oilseed rape as a cover crop has the ability to suppress some soil borne diseases of potato (Larkin et al., 2010). Therefore, the main aim of this research was to test how different organic cultivation technologies influence early blight development in disease-favourable conditions. A further aim was to test the suitability of a locally bred quite late blight resistant cultivar recommended for growing in an organic farming system.

\section{Materials and methods}

Field experiment. Early blight (Alternaria solani) was evaluated in 2010 and 2011 on the plants of a potato cultivar 'Reet' in an organic farming experiment of the Department of Field Crops and Grassland Husbandry, Estonian University of Life Sciences located at Eerika $\left(58^{\circ} 22^{\prime} \mathrm{N}, 26^{\circ} 40^{\prime} \mathrm{E}\right)$, near Tartu. The potato trial is part of a 5-year crop rotation experiment with red clover, winter wheat, peas, potato and barley following each other. The rotation experiment was started in 2008. Different field operations and their timing are shown in Table 1.

Table 1. Different field operations and their timing

\begin{tabular}{|c|c|c|}
\hline $\begin{array}{c}\text { Field } \\
\text { operation }\end{array}$ & $\begin{array}{l}\text { Experimental year } \\
2010\end{array}$ & $\begin{array}{c}\text { Experimental year } \\
2011\end{array}$ \\
\hline Cultivar & 'Reet' & 'Reet' \\
\hline Planting date & 6 May & 12 May \\
\hline \multirow{2}{*}{ Planting rate } & $3 \mathrm{tha}^{-1}$ & $3 \mathrm{t} \mathrm{ha}^{-1}$ \\
\hline & 57000 tubers ha ${ }^{-1}$ & 57000 tubers ha ${ }^{-1}$ \\
\hline Harvest date & 30 August & 24 August \\
\hline \multirow[t]{2}{*}{ Fertilization } & $\begin{array}{l}\text { winter cover crop }+ \\
\text { composted cattle } \\
\text { manure }- \\
20 \text { April }\end{array}$ & $\begin{array}{c}\text { winter cover crop + } \\
\text { composted cattle } \\
\text { manure - } \\
27 \text { April }\end{array}$ \\
\hline & $\begin{array}{l}40 \mathrm{t} \mathrm{ha}^{-1} \text { composted } \\
\text { cattle manure }\end{array}$ & $\begin{array}{l}40 \mathrm{t} \mathrm{ha}^{-1} \text { composted } \\
\text { cattle manure }\end{array}$ \\
\hline
\end{tabular}

Year 2010 was the third year for conversion to organic with 2011 the first fully organic year. Winter oilseed rape was used as a winter cover crop before the potato. The experiment was carried out in two different organic growing systems (treatments). In both, a winter cover crop (CC) for green manure (winter oilseed rape) was used; it was planted in both years in September and ploughed down in April the following year. No cattle manure was added to treatment $\mathrm{CC}$, whereas composted cattle manure (M) was added to the second treatment $\mathrm{CC}+\mathrm{M}$ (Table 1). There were four replicates of each treatment. The size of each test plot was $60 \mathrm{~m}^{2}$. The distance between seed tubers was $27 \mathrm{~cm}$ and the distance between rows was $70 \mathrm{~cm}$. In both years only certified seed potatoes were used. Seed tubers with a diameter of 35-55 mm were used. No fungicides, herbicides or insecticides were applied. The soil was Stagnic Luvisol $(L V j)$ by WRB 2006 classification (FAO, 2006), the texture of which is sandy loam with a humus layer of $20-30 \mathrm{~cm}$. No irrigation was used.

Weather conditions. In 2010, spring/summer temperature records (Eerika Weather Station) were similar to the long-term (20-year) average, except in July which was hotter by $4.2^{\circ} \mathrm{C}$ (Table 2). Rainfall in 2010 , was similar to the long-term average in June and August, but, in July, was lower with only $36 \mathrm{~mm}$ (20-year average is $69.3 \mathrm{~mm}$ ). In 2011, May, August and September temperature records were similar to the long-term average, but June was hotter by $1.9^{\circ} \mathrm{C}$ and July by $2.4^{\circ} \mathrm{C}$ (Table 2). Rainfall was much lower than the long-term average in June, July and August but in the first ten-day period of September more than the long-term average. In July, the warm (with temperatures over $30^{\circ} \mathrm{C}$ for more than 10 days) and humid conditions were conducive to early blight infection in the third ten-day period of July.

Early blight assessment. Disease assessments were made from 23 July to 27 August in 2010 (6 observations), and from 29 July to 2 September in 2011 ( 6 observations). Foliar disease was evaluated in natural infection conditions as a percentage of total foliage once each week, until harvesting. In each of the replications, 25 plants per plot were assessed. Early blight infection was assessed according to the $0-100 \%$ scale (Granovsky, Peterson, 1954). The area under the disease progress curve (AUDPC) was calculated from the date of first occurrence of early blight until the last observation of the disease in the trial according to Shaner and Finney (1977) by using the following formula: $\left.\Sigma_{\mathrm{i}}<\mathrm{n}[(\mathrm{Ri}+1+\mathrm{Ri}) / 2)\right]$ $\left(t_{i+1}-t_{i}\right)$, where $R_{i}$ is the disease severity (percentage leaf surface blighted) at the $i$ ths observation, $\mathrm{t}_{\mathrm{i}}$ - the time in days since the previous rating at the $i$ ths observation, and $n$ - the total number of observations. The early blight tuber assessment was made three months after harvest. From each replication, 100 tubers were randomly selected to characterize the total yield. A few days before the assessment the tubers were washed in order to see the lesions better.

Data analysis. Statistical analyses were performed with the programme Statistica 11 (StatSoft Inc., Tulsa, USA). The differences in the severity percentage of early blight between treatments were tested with one-way $A N O V A$. Kruskal-Wallis $A N O V A$ was used to determine the effects of year and cultivation technology on the early blight tuber infection as the data were not normally distributed. The dependence of AUDPC value and marketable yield of tubers on year and cultivation technology was analysed with type III ANOVA. Both factors such as "year" and "cultivation technology" were treated as fixed categorical variables. Tukey HSD post-hoc tests $(\alpha=0.05)$ were applied to find specific differences between years and cultivation technologies. Interactions between variables were also tested for. 
Table 2. Average monthly temperatures and rainfall at Eerika during the vegetation periods of 2010 and 2011 together with long-term averages (according to Eerika Weather Station, Estonia)

\begin{tabular}{|c|c|c|c|c|c|c|c|}
\hline \multirow[b]{2}{*}{ Month } & \multirow[b]{2}{*}{$\begin{array}{l}\text { Ten-day } \\
\text { period }\end{array}$} & \multicolumn{3}{|c|}{ Temperature ${ }^{\circ} \mathrm{C}$} & \multicolumn{3}{|c|}{ Rainfall $\mathrm{mm}$} \\
\hline & & $\begin{array}{c}\text { Average of } \\
2010\end{array}$ & $\begin{array}{c}\text { Average of } \\
2011\end{array}$ & $\begin{array}{l}\text { Average of } \\
1969-2011 \\
\end{array}$ & $\begin{array}{c}\text { Sum of } \\
2010\end{array}$ & $\begin{array}{c}\text { Sum of } \\
2011 \\
\end{array}$ & $\begin{array}{c}\text { Average sum of } \\
1969-2011\end{array}$ \\
\hline \multirow{3}{*}{ May } & I & 7.3 & 8.0 & 9.7 & 39.2 & 0.2 & 12.9 \\
\hline & II & 16.7 & 11.8 & 11.4 & 44.6 & 46.6 & 20.9 \\
\hline & III & 12.4 & 13.0 & 12.8 & 13.6 & 11.6 & 22.8 \\
\hline \multirow{3}{*}{ June } & I & 13.3 & 19.7 & 14.9 & 41.4 & 0.0 & 20.9 \\
\hline & II & 13.6 & 15.9 & 15.1 & 17.8 & 24.8 & 26.9 \\
\hline & III & 15.9 & 16.2 & 16,2 & 38.8 & 10.4 & 28.0 \\
\hline \multirow{3}{*}{ July } & I & 19.9 & 20.0 & 17.3 & 11.6 & 9.2 & 19.3 \\
\hline & II & 22.9 & 18.6 & 17.4 & 3.0 & 30.4 & 24.8 \\
\hline & III & 22.4 & 21.0 & 17,8 & 23.8 & 8.6 & 26.5 \\
\hline \multirow{3}{*}{ August } & I & 20.9 & 16.1 & 17.6 & 18.2 & 16.2 & 33.3 \\
\hline & II & 19.1 & 15.6 & 16.2 & 74.6 & 17.0 & 28.5 \\
\hline & III & 13.7 & 15.8 & 14.6 & 55.6 & 21.4 & 28.0 \\
\hline \multirow{2}{*}{ September } & I & 10.4 & 13.0 & 12.7 & 32.6 & 32.2 & 20.3 \\
\hline & II & 12.1 & 12.2 & 10.6 & 46.4 & 28.4 & 18.3 \\
\hline May-September & I-III & 15.8 & 14.8 & 14.6 & 461.2 & 257.0 & 331.5 \\
\hline
\end{tabular}

\section{Results}

Development of foliar early blight. In both years, early blight was the primary foliar disease on the trial plots. Infection by potato late blight was not recorded in either year. Both growing seasons were very favourable for early blight development and evaluation, with weather conditions even more favourable in 2011 than in 2010. In 2010, the first early blight symptoms were recorded on 23 July, with both treatments infected (Fig. 1 a). The disease-conducive conditions allowed rapid establishment and progression of the disease from the time the first symptoms had been recorded. Winter cover crop (CC) plots had significantly slower progression at the beginning of disease development than the $\mathrm{CC}+\mathrm{M}$ (manure) plots (29 July, $p=0.003 ; 5$ August, $p=0.66$ ) (Fig. $1 \mathrm{a}$ ) and the disease developed more slowly on the CC plots than on the $\mathrm{CC}+\mathrm{M}$ plots $\left(F_{5,18}=54.70, p<0.0001\right.$, Tukey HSD test $p<0.05)$. By the end of growing season, $50 \%$ of foliage was destroyed by early blight on the $\mathrm{CC}+$ M plots and $40 \%$ on the CC plots. In 2011, the first early blight symptoms were found on 29 July with both CC and $\mathrm{CC}+\mathrm{M}$ plots infected (Fig. $1 \mathrm{~b}$ ). Disease developed

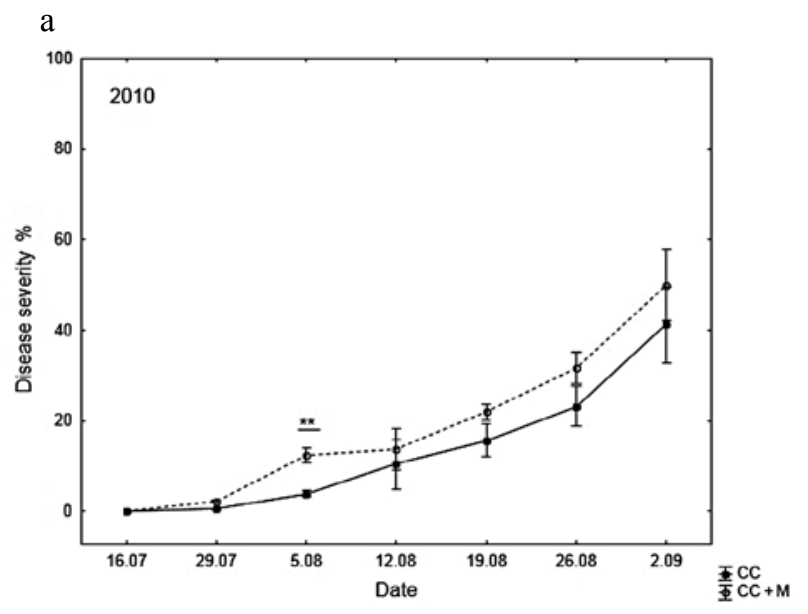

moderately until 12 August and thereafter increased abruptly (Fig. $1 \mathrm{~b}$ ). At the beginning of the observation period, early blight developed significantly more rapidly on the $\mathrm{CC}+\mathrm{M}$ than on the $\mathrm{CC}$ plots. On 26 August, both treatments were similarly infected, but later again the $\mathrm{CC}$ treatment developed more slowly than the $\mathrm{CC}+\mathrm{M}$ (Fig. 1 b). On the CC $+\mathrm{M}$ plots more than $80 \%$ of the foliage was destroyed by 2 September (Fig. 1 b). Disease severity in the $\mathrm{CC}+\mathrm{M}$ plots increased from less than $2 \%$ at the start to more than $83 \%$ within five weeks.

The early blight tuber infection. Infection of tubers by early blight was found in both years. In both 2010 and 2011, it was higher on the CC + M plots than on the $\mathrm{CC}$ plots, although not statistically so $(\mathrm{H}(1, \mathrm{~N}=16)=$ $0.631, p=0.427$ ) (Table 3). Data also showed differences between years; tuber infection was higher in 2011 than in 2010 , but not statistically significant $(\mathrm{H}(1, \mathrm{~N}=16)=$ 2.527, $p=0.112$ )

Resistance evaluation using area under the disease progress curve (AUDPC). Both growing years were very favourable for early blight foliar resistance

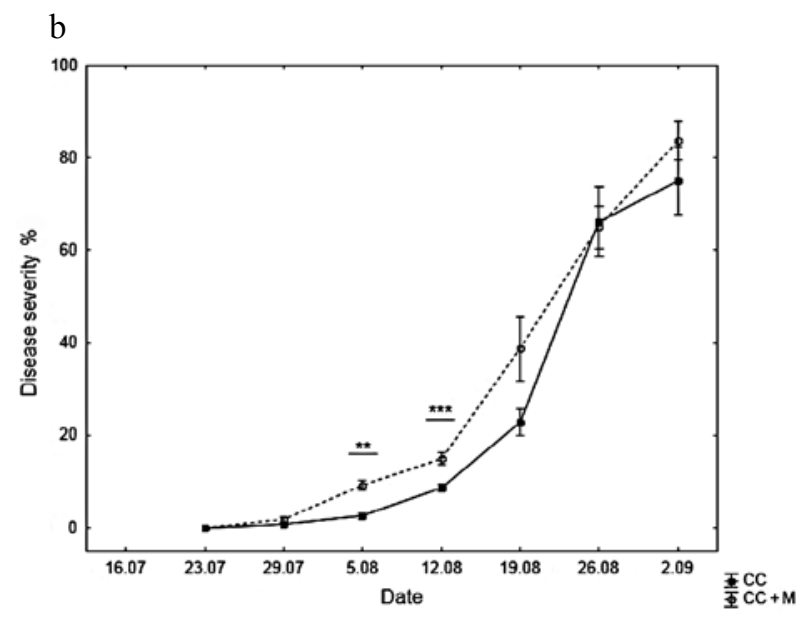

${ }^{*}-p<0.05, * *-p<0.01($ ANOVA $)$

Figure 1. Development of potato early blight on organic plots with previous cover crops (CC) or with cover crops and added cattle manure $(\mathrm{CC}+\mathrm{M})$ in 2010 (a) and 2011 (b) 
Table 3. Results of the early blight tuber infection (\%)

\begin{tabular}{ccc}
\hline \multirow{2}{*}{ Treatments } & \multicolumn{2}{c}{ Year } \\
\cline { 2 - 3 } & 2010 & 2011 \\
\hline Organic CC & $0.25 \mathrm{a}$ & $1 \mathrm{a}$ \\
Organic CC $+\mathrm{M}$ & $0.5 \mathrm{a}$ & $1.75 \mathrm{a}$ \\
\hline
\end{tabular}

Note. a - statistically significant differences between treatments not found; $\mathrm{CC}$ - winter cover crop, $\mathrm{CC}+\mathrm{M}$ - winter cover crop + composted cattle manure.

evaluations; still early blight pressure was different in 2010 and 2011. Significant differences were found in AUDPC values between the two years $\left(F_{1,12}=19.29\right.$, $p<0.001$ ) (Fig. 2). In both years, AUDPC values were very high; the mean AUDPC in 2010 was 632 and, in 2011, even higher - 1081 (Fig. 2). Significant differences between the two cultivation technologies were found $\left(F_{1,12}=4.84, p=0.048\right)$. In 2010, the AUDPC value was 303 on CC plots and 990 on CC + M plots, that is three times higher (Fig. 2), whereas in 2011, the AUDPC value was 967 on CC plots 1195 on CC + M plots (Fig. 1). There was no interaction between cultivation technology and year $\left(F_{1,12}=0.0008, p=0.978\right)$.

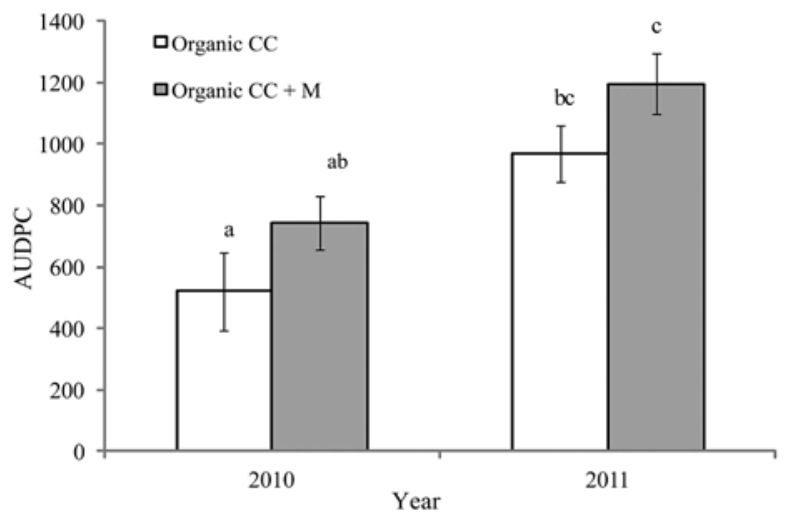

Notes. The boxes indicate the mean value and whiskers the standard error of the mean. Different letters above the boxes indicate statistically significant differences among treatments (ANOVA, Tukey HSD test). Potatoes were grown on plots following a cover crop (CC) of winter oilseed rape and with $(\mathrm{CC}+\mathrm{M})$ or without added cattle manure.

Figure 2. Mean area under the disease progress curve (AUDPC) values of foliar early blight in organic potato field trials in 2010-2011

Early blight effect on potato tuber yield. There were significant differences in marketable tuber yield between years $\left(F_{1,12}=16.33, p=0.0016\right)$ and treatments $\left(F_{1,12}=8.39, p=0.013\right)$ (Fig. 3). In 2010, marketable tuber yield was approximately $9 \mathrm{t} \mathrm{ha}^{-1}$ lower than in 2011 (Fig. 3), although there were no differences in marketable yield between treatments. In 2011, marketable tuber yield was $8 \mathrm{tha}^{-1}$ higher on $\mathrm{CC}+\mathrm{M}$ plots than on $\mathrm{CC}$ plots.

\section{Discussion}

This study indicates that potato early blight is a great problem for potato growing in an organic farming system, and especially so in years with higher than average temperature. In both our study years, the severe early blight infection caused defoliation, especially in 2011 on the plots with added cattle manure $\mathrm{CC}+\mathrm{M}$, where more than $80 \%$ of foliage was killed. The direct

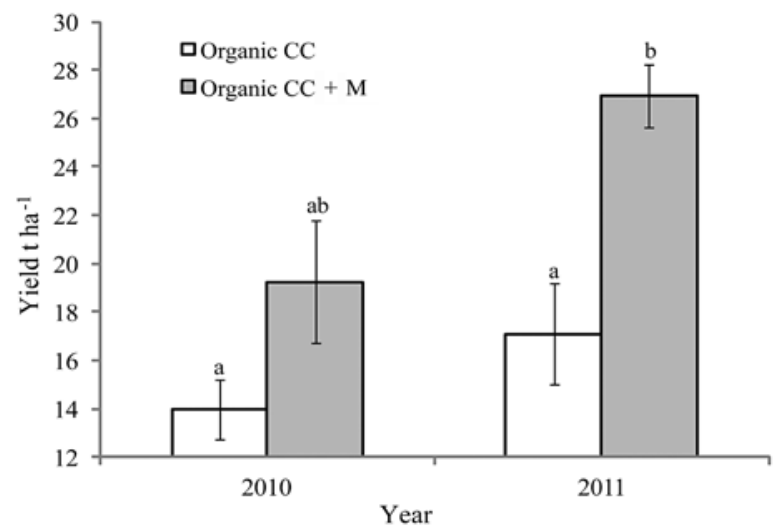

Figure 3. Marketable potato tuber yields in 2010 and 2011 from organically farmed plots with a previous cover crop (CC), winter oilseed rape, some with and without added cattle manure $(\mathrm{M})$

cause of this was probably the extremely low rainfall in May, June and July in 2011 compared to the long-term average. Drought influences the normal functioning of potato plants; stressed plants are more susceptible to early blight. The early blight pathogens are typical examples of a necrotrophic organism, where a pathogen infects weaker and older plants (Rotem, 1994). The same trend of a recent increase in damage by potato early blight has been reported from other European countries, including some where potato early blight has been problematic for some time, for instance in south-eastern Sweden (Blixt, Andersson, 2010) and in Germany (Leiminger et al., 2010). In Poland, regional losses of up to $45 \%$ have been found, mostly associated with cultivars with recognized susceptibility to early blight (Kapsa, Osowski, 2004), and Kapsa and Osowski (2011) have reported a recent increase in the importance of the disease.

In our two year study, the $\mathrm{CC}+\mathrm{M}$ plots gave higher potato yields than the $\mathrm{CC}$ plots despite having more of their foliage destroyed by early blight disease. These results seem quite contrary to the findings in the literature. Early canopy defoliation reduces assimilate accumulation in the tubers (Rotem, 1994) resulting in yield loss (Shtienberg et al., 1990). James et al. (1972) have stated that the tuber-filling process paralyzes when defoliation reaches over $75 \%$. Researchers Campo Arana et al. (2007) have observed even more serious consequences of early blight damage, where, at $50 \%$ to $100 \%$ defoliation, yield loss was about $55 \%$. Both our cultivation systems had significant differences in AUDPC value, with both levels quite high. Therefore, early blight defoliation apparently did not have as great an effect on marketable yield as fertilization with cattle manure. On the other hand, $\mathrm{CC}+\mathrm{M}$ plots had a more nutritious soil due to the cattle manure, supplying nutrients earlier and enabling higher tuber yields.

The lower crop yields we obtained in 2010 are quite hard to explain, because disease pressure was lower and overall humidity conditions were more favourable in 2010 than in 2011. Still, after potato plants emerged in June in 2011 , it was $3^{\circ} \mathrm{C}$ warmer than in 2010 . Also, in July 2010, there were several days with an air temperature above $28^{\circ} \mathrm{C}$. Temperature is a major factor regulating biomass accumulation and tuber development in potatoes. Cao and Tibbitts (1994) have indicated that tuber development of potatoes is optimized by high 
temperature during early growth and low temperature during later growth.

AUDPC values were lower on our CC plots than on $\mathrm{CC}+\mathrm{M}$ plots, even though the former were less fertilized. There is less information available about early blight damage on potato and its relation to obtaining nutrients in an organic growing system. For comparison, in conventional potato growing increased rates of nitrogen fertilizer application reduce the apparent infection rate and the final amount of early blight disease (MacKenzie, 1981). Also, Christ and Haynes (2001) showed that application of more fertilizer and low rainfall in the early part of the season prevented an early blight epidemic. An initial result of our research indicated that manure inhibits the suppressive effect of winter oilseed rape. We could only hypothesize that the suppressive cover crop effect of winter oilseed rape appeared clearer on the treatment without cattle manure.

Genetic resistance of cultivars to pathogens is a major factor for consideration where there is severe pressure from the early blight pathogen (Kapsa, Osowski, 2011). Even the late blight resistant potato cultivar 'Reet' is recommended by breeders for economical cultivation (Tsahkna, Tähtjärv, 2008), although our experience has shown that, in a dry and hot growing season, conditions are favourable for a very severe early blight infection that destroys most of the foliage. The early blight damage evaluation showed that foliage was notably less destroyed by disease in CC plots than in the CC + $\mathrm{M}$ plots. As our results have indicated, it is possible to influence the development severity of early blight by selection of growing technology, although further work is necessary. As early blight is not the main foliar disease of potato in Estonia, the extraordinarily heavy early blight infection was not expected. A very severe outbreak of early blight occurred in the organic plots and destroyed most of the canopy. Therefore, from the experience of this two-year trial we can state, that besides the threat from potato late blight, potato early blight can also cause serious infection in Estonia and thus, early blight susceptible potato cultivars cannot be recommended for an organic farming system. From our results, we conclude that for environmentally-friendly farming early blight resistant potato cultivars should be grown in both organic and conventional growing systems. In an organic farming system, chemical control is not allowed and, in conventional systems, the disease requires the application of expensive fungicides.

In changed warmer climatic conditions, new pathogens will give rise to new problems in the future (Jönsson et al., 2013). Our results confirm that potato early blight has already become a more serious problem for North-East European organic potato growers. In the future, we need to investigate what is behind the more serious early blight infections: warmer summers (the global climate change), more susceptible cultivars or even changes in pathogen epidemiology?

\section{Conclusions}

1. Potato early blight is a grave problem for potato growing in an organic farming system, and especially in years with higher than average temperatures.

2 . In both our study years, early blight infection was more severe in the plots with added cattle manure $(\mathrm{CC}+\mathrm{M})$ than in the cover crop $(\mathrm{CC})$ plots.
3. The development severity of early blight can be influenced by selecting appropriate growing technology, but more research on this is needed.

4. In the changed climatic conditions, early blight can cause early defoliation of plants and crop death in susceptible cultivars, indicating the need for resistant potato cultivars.

\section{Acknowledgements}

The study was supported by the Estonian Foundation grants Nos. 9432 and 9450; Target Financing SF170057s09, projects RESIST 3.2.0701.11-0003 and TILMAN-ORG.

Received 29052013

Accepted 15102013

\section{References}

Blixt E., Andersson B. 2010. Occurrence of Alternaria solani in Sweden and its sensitivity to strobilurins. PPO Special Report, 14: 161-163

Campo Arana R. O., Zambolim L., Costa L. C. 2007. Potato early blight epidemics and comparison of methods its initial symptoms in a potato field. Revista Facultad Nacional de Agronomía Medellin, 60 (2): 3877-3890

Cao W., Tibbitts T. W. 1994. Phasic temperature change patterns affect growth and tuberization in potatoes. Journal of the American Society for Horticultural Science, 119 (4): 775-778

Christ B. J., Haynes K. G. 2001. Inheritance of resistance to early blight disease in a diploid potato population. Plant Breeding, 120 (2): 169-172 http://dx.doi.org/10.1046/j.1439-0523.2001.00565.x

Cooke L. R., Schepers H. T. M., Hermansen A., Bain R. A., Bradshaw N. J., Ritchie F., Shaw D. S., Evenhuis A., Kessel G. J. T., Wander J. G. N., Anderson B., Hansen J. G., Hannukkala A., Nærstad R., Nielsen B. J. 2011. Epidemiology and integrated control of potato late blight in Europe. Potato Research, 54: 183-222 http://dx.doi.org/10.1007/s11540-011-9187-0

Dita Rodriguez M. A., Brommonschenkel S. H., Matsuoka K., Mizubuti E. S. G. 2006. Components of resistance to early blight in four potato cultivars: effect of leaf position. Journal of Phytonathologv. 154 (4): 230-235 http://dx.doi.org/10.1111/j.1439-0434.2006.01089.x

FAO 2006. World Reference Base for Soil Resources 2006. World Soil Resources Report 103. Food and Agriculture Organization of the United Nations. Rome, 145 p. $<\mathrm{ftp}: / / \mathrm{ftp}$. fao.org/agl/agll/docs/wsrr103e.pdf $>$ [accessed 0105 2013]

Granovsky A. A., Peterson A. G. 1954. Evaluation of potato injury caused by 10 leafhoppers, flea beetles, and early blight. Journal of Economic Entomology, 47: 894-902

Gudmestad N. C., Pasche J. S. 2007. Role of fenamidone in the management of potato early blight - Alternaria solani. Proceedings of the $10^{\text {th }}$ workshop of an European network for development of an integrated control strategy of potato late blight. PPO-Special Report No. 12. Bologna, Italy, p. $175-182$

James W. C., Shih C. S., Hodgson W. A., Callbeck L. C. 1972. The quantitative relationship between late blight of potato and loss in tuber vield. Journal of Phytopathology, 62 (1): 92-96 http://dx.doi.org/10.1094/Phyto-62-92

Jönsson A. M., Pulatov B., Linderson M. L. 2013. Modelling as a tool for analysing the temperature-dependent future of the Colorado potato beetle in Europe. Global Change Biology. 19 (4): 1043-1055 http://dx.doi.org/10.1111/gcb.12119

Kapsa J., Osowski J. 2004. Occurrence of early blight (Alternaria ssp.) at potato crops and results of its chemical control in Polish experiences. Proceedings of the $8^{\text {th }}$ workshop of an European network for development of an integrated control strategy of potato late blight. PPO-Special Report No. 10. Jersey, Channel Islands, p. 101-107 
Kapsa J., Osowski J. 2011. Host-pathogen interaction between Alternaria species and $S$. tuberosum under different conditions. Proceedings of the $13^{\text {th }}$ EuroBlight Workshop. PPO-Special Report No. 15. St. Petersburg, Russia, p. $107-112$

Kocmánková E., Trnka M., Eitzinger J., Formayer H., Dubrovský M., Semerádová D., Žalud Z., Juroch J., Možný M. 2010. Estimating the impact of climate change on the occurrence of selected pests in the Central European region. Climate Research. 44: 95-105 http://dx.doi.org/10.3354/cr00905

Larkin R. P., Griffin T. S., Honeycutt C. W. 2010. Rotation and cover crop effects on soilborne potato diseases, tuber yield, and soil microbial communities. Plant Disease. 94 (12): 1491-1502 http://dx.doi.org/10.1094/PDIS-03-10-0172

Latorse M. P., Schmitt F., Peyrard S., Veloso S., Beffa R. 2010. Molecular analysis of Alternaria populations early blight causal agents in potato plants. Proceedings of the $12^{\text {th }}$ EuroBlight Workshop. PPO-Special Report No. 14. Arras, France, p. 179-186

Leiminger J., Hausladen H. 2012. Early blight control in potatoes using disease orientated threshold values. Plant Disease. 96 (1): 124-130 http://dx.doi.org/10.1094/PDIS-05-11-0431

Leiminger J., Bahnweg G., Hausladen H. 2010. Population genetics - consequences on early blight disease. Proceedings of the $12^{\text {th }}$ EuroBlight Workshop. PPO-Special Report No. 14. Arras, France, p. 171-177

MacKenzie D. R. 1981. Association of potato early blight, nitrogen fertilizer rate. and potato vield. Plant Disease, 65: 575-577 http://dx.doi.org/10.1094/PD-65-575

Pelletier J. R., Fry W. E. 1989. Characterization of resistance to early blight in three potato cultivars: incubation period, lesion expansion rate, and spore production. Phvtopathologv. 79: 511-517 http://dx.doi.org/10.1094/Phyto-79-511

Rotem J. 1994. The genus Alternaria: biology, epidemiology and pathogenicity

Runno-Paurson E., Fry W. E., Remmel T., Mänd M., Myers K. L. 2010. Phenotypic and genotypic characterisation of
Estonian isolates of Phytophthora infestans in 2004-2007. Journal of Plant Pathology, 92 (2): 375-384

Runno-Paurson E., Kotkas K., Tähtjärv T., Williams I. H., Mänd M. 2011. Temporal changes in phenotypic diversity of Phytophthora infestans in northern Estonia. ZemdirbysteAgriculture, 98 (2): 205-212

Runno-Paurson E., Hannukkala A., Williams I., Koppel M., Mänd M. 2012. The structure of mating type, virulence, metalaxyl resistance of Phytophthora infestans in a longterm phenotypic study in distinct location in Eastern Estonia. Journal of Plant Diseases and Protection, 119 (2): 45-52

Runno-Paurson E., Williams I., Metspalu L., Kaart T., Mänd M. 2013. Current potato varieties are too susceptible to late blight to be grown without chemical control under NorthEast European conditions. Acta Agriculturae Scandinavica Section B: Soil and Plant Science, 63 (1): 80-88

Runno-Paurson E., Hannukkala A., Kotkas K., Koppel M., Williams I. H., Mänd M. 2014. Population changes and phenotypic diversity of Phytophthora infestans isolates from Estonia and Finland. Journal of Plant Pathology, 96 (1): 85-95

Salonen J., Bromand B., Nistrup-Jorgensen L. 2001. Crop production conditions in the northern European region with a special reference to crop protection. Dias Report, 59: $120-125$

Shaner G., Finney R. E. 1977. The effect of nitrogen fertilization on the expression of slow-mildewing resistance in Knox wheat. Journal of Phytopathology. 67 (2):1051-1056 http://dx.doi.org/10.1094/Phyto-67-1051

Shtienberg D., Bergeron S. N., Nicholson A. G., Fry W. E., Ewing E.E. 1990. Development and evaluation of general model for yield loss assessment in potatoes. Phytopathologv. 80: 466-472 http://dx.doi.org/10.1094/Phyto-80-466

Treikale O., Rude O., Pugacheva J., Lazareva L. 2008. The development of Alternaria solani Sor. on potatoes cultivated in monoculture. Zemdirbyste-Agriculture, 95 (3): 202-208

Tsahkna A., Tähtjärv T. 2008. The new potato variety 'Reet'. Latvian Journal of Agronomy, 11: 159-164

ISSN 1392-3196 / e-ISSN 2335-8947

Zemdirbyste-Agriculture, vol. 101, No. 2 (2014), p. 199-204

DOI $10.13080 / \mathrm{z}-\mathrm{a} .2014 .101 .026$

\title{
Auginimo technologijos ịtaka bulvių sausligès (Alternaria solani) plitimui ekologinèje žemdirbystès sistemoje
}

\author{
E. Runno-Paurson, M. Hansen, B. Tein, K. Loit, K. Jogi, A. Luik, L. Metspalu, V. Eremeev, \\ Ingrid H. Williams, M. Mänd
}

Estijos gyvybės mokslų universiteto Žemės ūkio ir aplinkos mokslų institutas

\section{Santrauka}

Pastaruoju metu ekologiški produktai tapo itin populiarūs, ir susidomèjimas jais vis didèja. Bulvių sausligès sukèlèjas Alternaria solani anksčiau nebuvo laikomas itin grèsmingu bulvėms šiaurinio klimato sąlygomis, todèl nuo šios ligos bulvès nebuvo reguliariai purškiamos. Tyrimo metu bulvių sausligè vertinta 2010 ir $2011 \mathrm{~m}$., vykdant ekologinès žemdirbystès bandymą su veislès 'Reet' bulvėmis. Abiem tyrimų metais bulvių vegetacijos laikotarpis buvo labai palankus bulviu sausligès vystymuisi. Tarp dviejų auginimo technologiju nustatyti esminiai skirtumai $\left(F_{12}=4,84, p=0,048\right) .2010 \mathrm{~m}$. ligos pažeistų lapų ploto indeksas (AUDPC) buvo 303 antsẻlinių augalų laukeliuose ir 990 antsėlinių augalų bei méšlo laukeliuose, t. y. tris kartus didesnis. $2011 \mathrm{~m}$. AUDPC indeksas buvo 967 antsėlinių augalų laukeliuose ir 1195 antsėlinių augalų bei méšlo laukeliuose. Tyrimo rezultatai patvirtina, kad sausligè tapo rimta problema Šiaurès Rytų Europoje ekologiškai auginamų bulvių laukuose, todėl ekologinès žemdirbystės sistemoje nerekomenduotina auginti sausligei jautrių veislių bulvių. Sausligès vystymosi intensyvumui gali turèti ịtakos bulvių auginimo technologija. Kintančio klimato sąlygomis auginant sausligei jautrių veislių bulves, dèl šios ligos augalai anksti numeta lapus ir gali žūti, todèl yra poreikis kurti šiai ligai atsparių veislių bulves.

Reikšminiai žodžiai: Alternaria solani, ekologinė auginimo sistema, ligos intensyvumas. 